\title{
Cytotoxic potential of Anisochilus carnosus (L.f.) wall and estimation of luteolin content by HPLC
}

\author{
Jaykumar Bhagat ${ }^{1}$, Richard Lobo ${ }^{1 *}$, Nimmy Kumar ${ }^{1}$, Jessy Elizabeth Mathew ${ }^{2}$ and Aravinda Pai ${ }^{2}$
}

\begin{abstract}
Background: Anisochilus carnosus (L.f.) wall (Lamiaceae), an annual herb which grows at high altitude is used extensively in folk medicine for the treatment of ailments such as gastric ulcer and skin diseases. The aim of our study was to evaluate the anticancer activity of different extracts of the leaves of A.carnosus. An attempt was also made to estimate the luteolin content in different extracts of Anisochilus carnosus by HPLC (High Performance Liquid Chromatography).

Methods: In the current study, we explored the cytotoxic potential of petroleum ether, ethanolic and aqueous extracts of A.carnosus against breast adenocarcinoma cell line (BT-549), by in vitro MTT and SRB assay. We also detected the luteolin content in different extracts (ethanolic and aqueous) of A.carnosus by using HPLC as a tool of analysis.

Results: The results demonstrate that petroleum ether and ethanolic extract of A.carnosus showed potent cytotoxic effect against BT-549 with an $\mathrm{IC}_{50}$ of $22.5 \mu \mathrm{g} / \mathrm{ml}$ (petroleum ether extract) and $87.24 \mu \mathrm{g} / \mathrm{ml}$ (ethanolic extract), by SRB assay, and $18.35 \mathrm{\mu g} / \mathrm{ml}$ (petroleum ether extract) and $58.64 \mu \mathrm{g} / \mathrm{ml}$ (ethanolic extract), by MTT assay. The aqueous extracts showed less cytotoxic effect with an IC 50 of $211.26 \mu \mathrm{g} / \mathrm{ml}$ (by SRB assay) and $238.91 \mu \mathrm{g} / \mathrm{ml}$ (by MTT assay). HPLC results of luteolin content in various extracts using luteolin as the marker compound indicated the ethanol extract to contain the highest concentration of luteolin $(0.372 \% \mathrm{w} / \mathrm{w})$. The aqueous extract contained lower concentration of luteolin $(0.282 \% \mathrm{w} / \mathrm{w})$.
\end{abstract}

Conclusion: Our findings demonstrate that petroleum ether and ethanolic extract of A.carnosus shows promising anticancer activity and has the potential to be developed into a therapeutic option for the treatment of cancer.

Keywords: A.carnosus, Anticancer activity, BT-549, Luteolin, High performance liquid chromatography

\section{Background}

Breast cancer continues to be the second most common cause of cancer associated death among women [1]. It is projected that 1 in every 8 women will develop breast cancer in their lifetime [2]. Based on the ACS (American Cancer Society) report 2014, there are a possibility of $1,665,54$ new cases of breast cancer and an estimated 585,720 people will die of this disease [3]. The risk factors for breast cancer include female sex, menarche at an early age, menopause at a late age, a family history of cancer, innate germ-line mutations in tumour-suppressor genes (e.g., BRCA1, BRCA2, and p53), late age at first pregnancy or never having given birth, regular alcohol use, use of menopausal hormone therapy (MHT) and ionising

\footnotetext{
* Correspondence: avemaria_lobo@yahoo.com

${ }^{1}$ Department of Pharmacognosy, Manipal College of Pharmaceutical

Sciences, Manipal University, Manipal, Karnataka 576 104, India

Full list of author information is available at the end of the article
}

radiation exposure [1,4]. Although, high dose chemo and radiotherapy have drastically increased the long term survival of breast cancer patients, they are associated with severe side effects such as nausea, vomiting, alopecia [5], cancer-related fatigue [6] and cardiovascular complications [1].

Several findings have indicated that more than twothird of human cancers could be averted through suitable lifestyle modification. According to Richard Doll and Richard Peto, 35\% of death due to cancer is attributable to diet [7]. In this regard, nutritional phytochemicals and plant derived constituents such as flavonoids, phytosterols, triterpenoids and essential oils hold enormous possibilities for development of a therapy with considerably fewer side effects for treatment and prevention of cancer [8]. Studies have signified that they can alter multiple pathways at the same time and inhibit tumour

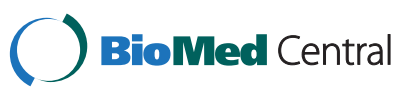

(c) 2014 Bhagat et al.; licensee BioMed Central Ltd. This is an Open Access article distributed under the terms of the Creative Commons Attribution License (http://creativecommons.org/licenses/by/4.0), which permits unrestricted use, distribution, and reproduction in any medium, provided the original work is properly credited. The Creative Commons Public Domain Dedication waiver (http://creativecommons.org/publicdomain/zero/1.0/) applies to the data made available in this article, unless otherwise stated. 
promoting pathways while also activating tumour suppressor pathways $[7,8]$. They can block or reverse two stages of tumour development namely tumour initiation and tumour promotion and thus terminate or impede the development of precancerous cells into malignant ones [7]. One such class of nutritional phytochemical that have been identified to have incredible cancer-protective effects is flavonoids. Luteolin is a naturally occurring flavonoid that can be found in a variety of fruits, vegetables and medicinal herbs [9]. Many epidemiological studies suggest a reverse relation between luteolin consumption and risk of some cancer types. Anisochilus carnosus (L.f.) wall, a member of the family Lamiaceae is an annual herb which grows on high altitude among small rocks. In India, it is widely distributed in Tamil Nadu, Karnataka, Maharashtra and Rajasthan [10] and is known as Induparni in Sanskrit, Panjiri-ka patta in Hindi and Kapurli in Marathi [11]. Traditionally, it is widely used by many tribal communities of Tamil Nadu, Maharashtra and Rajasthan for the treatment of cough, ulcer, eczema and stomach ache [12-16]. Phytochemical analysis of this plant showed it to be rich in active compounds such as flavonoids (luteolin, apigenin) [17], phytosterols, triterpenoids, saponins, tannins [18] and essential oil components (carvacrol, $\alpha$-cis-bergamotene, caryophyllene, $\beta$-selinene, camphor) [19].

This paper reports the anticancer activity of different extracts of A.carnosus against BT-549, an estrogen independent breast adenocarcinoma cell line. This study also aims to determine the luteolin content in different extracts of the plant and correlate the luteolin content of extracts to its anticancer activity.

\section{Methods}

\section{Plant collection}

The leaves of A.carnosus was collected from Udyavar, Udupi in September 2010 and authenticated by Dr. Richard Lobo, Pharmacognosist, Manipal College of Pharmaceutical sciences, Manipal, Karnataka. A voucher specimen with accession number [PP 573] has been deposited in the Department of Pharmacognosy, Manipal College of Pharmaceutical Sciences, Manipal, India.

\section{Reagent and chemicals}

The reagents MTT (3-(4, 5-dimethylthiazol-2-yl)-2, 5diphenyltetrazolium bromide) and SRB (Sulforhodamine B) were purchased from Sigma Aldrich, USA. Methanol, ethanol (95\%), chloroform, petroleum ether, acetone and benzene were purchased from Ranbaxy Fine Chemicals Ltd. The reference standard luteolin was obtained from Sigma Aldrich, USA. All solvents purchased were of analytical grade.

\section{Extraction and fractionation}

The dried coarsely powdered leaves of A.carnosus (500 g) was extracted with solvents petroleum ether $\left(60-80^{\circ} \mathrm{C}\right)(3 \mathrm{x}$ $1 \mathrm{~L})$ and ethanol ( $3 \times 1 \mathrm{~L})$ using soxhlet extractor. The solvent- containing extracts were evaporated to dryness on a rotary evaporator under reduced pressure to obtain percentage yield of $23.8 \% \mathrm{w} / \mathrm{w}$ and $17 \% \mathrm{w} / \mathrm{w}$ respectively. Crushed shade-dried leaves (500 g) were kept for cold maceration in chloroform: water (1:99) for 4 days at room temperature. The solvent-containing extract was then filtered and filtrate obtained was concentrated on a water bath to obtain crude aqueous extract $(16.2 \% \mathrm{w} / \mathrm{w})$.

\section{Human cell line and culture medium Cell line}

Breast tumour carcinoma cell line BT-549 was obtained from NCCS (National Centre for Cell Sciences) Pune, India. DMEM (Dulbecco's Modified Eagles Medium) media and Foetal bovine serum (FBS) was obtained from Sigma Aldrich, USA.

\section{In vitro MTT assay}

The cytotoxicity of A.carnosus against BT-549 cell line was determined using the Methyl thiazol tetrazolium (MTT) assay [20]. BT-549 (Breast tumour carcinoma) cells were harvested from $75 \mathrm{~cm}^{2}$ tissue culture flasks and inoculated into 96-well flat bottom tissue culture plate $\left(10^{4}\right.$ cells/well in $0.1 \mathrm{ml}$ of MEM [Minimum Essential medium] supplemented with 10\% FBS [Foetal Bovine Serum]) and incubated for 24 hours for attachment. Test compounds were solubilised just prior to the experiment in $0.1 \%$ DMSO. After incubation for 24 hours, cells were subjected to several concentrations of the extracts (25, 50, 100 and $200 \mu \mathrm{g} / \mathrm{ml})$. The cells which received only the medium containing $0.1 \%$ DMSO served as the control group. Paclitaxel was used as standard. After the treatment, the media was removed and washed with $200 \mu \mathrm{l}$ of PBS. To each well of the 96 well plates, $100 \mu \mathrm{l}$ of MTT reagent was added and incubated for 4 hours at $37^{\circ} \mathrm{C}$. After 4 hours of incubation, the plate was inverted on a tissue paper to remove MTT reagent. To solubilize the formazan crystals in the wells, $100 \mu \mathrm{l}$ of DMSO was added to each well. The suspension was placed on a micro-vibrator for 5 minutes and the optical density (O.D) was measured by a microplate reader at $570 \mathrm{~nm}$. Percentage viability of each extract was calculated by using the formula:

$$
\begin{aligned}
\% \text { Cell Viability }= & 100-\left[\left(\text { O. } D_{\text {control }}\right)-\left(\text { O. } D_{\text {sample }}\right) /\left(\text { O. } D_{\text {control }}\right)\right] \\
& \times 100
\end{aligned}
$$

The experiment was performed in three biological replicates. Results were expressed as Mean \pm SEM 
values. \% cell viability was plotted against the tested drug concentrations.

\section{In vitro SRB assay}

Cell proliferation and viability was determined by a sulforhodamine B (SRB) colorimetric assay [21]. Briefly, BT-549 cells were plated onto 96-well flat bottom tissue culture plate at a density of $10^{4}$ cells/well and incubated for 24 hours. Subsequently, cells were treated with various concentrations of the extract $(25,50,100,200 \mu \mathrm{g} / \mathrm{ml})$. The cells in the control group received only the medium containing 0.1\% DMSO. Paclitaxel was used as standard. After 48 hours, the cells were fixed with icecold trichloroacetic acid $(100 \mu \mathrm{l}$ per well, $10 \% \mathrm{w} / \mathrm{v})$ for 1 hour at $4^{\circ} \mathrm{C}$. The plates were washed in distilled water and allowed to dry. $100 \mu \mathrm{l} \mathrm{SRB}(0.057 \% \mathrm{w} / \mathrm{v}$ in $1 \%$ aqueous acetic acid) solution was added to the dry 96-well plates in each well and allowed staining to occur at room temperature for $30 \mathrm{~min}$. The sulforhodamine (SRB) solution was removed by washing the plate five times with $1 \% \mathrm{v} / \mathrm{v}$ acetic acid in order to remove unbound dye. Washed plates were then dried. $200 \mu \mathrm{l}$ of $10 \mathrm{mM}$ Tris Base ( $\mathrm{pH}$ 10.5) was added to each well to solubilize the bound SRB. It was then shaken for 5$10 \mathrm{~min}$ on a shaker platform. Lastly, the plates were read in a 96-well plate reader with working wavelength of $570 \mathrm{~nm}$. The O.D of SRB in each well is directly proportional to the cell number so the O.D values can be plotted against concentration and the $\mathrm{IC}_{50}$ determined. The viability and growth in the presence of test material is calculated by following formula:

$$
\% \text { Cell Viability }=100-\left[\left(\text { O. }_{\text {control }}\right)-\left(\text { O. }_{\text {sample }}\right) /\left(\text { O. }_{\text {control }}\right)\right]
$$
$\times 100$

\section{HPLC estimation of Luteolin}

Samples for HPLC were prepared from the leaves of $A$. carnosus extract. $10 \mathrm{mg}$ of ethanolic and aqueous extract were weighed and separately dissolved in HPLC grade methanol. They were filtered through a $0.2 \mu \mathrm{m}$ syringe filter and transferred to $2 \mathrm{ml}$ eppendorf tubes. The volume was made up to $2 \mathrm{ml}$ with methanol to obtain $5 \mathrm{mg} / \mathrm{ml}$ concentration. These solutions were further used for HPLC estimation as test samples. Reference standard luteolin was prepared by weighing $0.1 \mathrm{mg} / \mathrm{ml}$ of luteolin and dissolving in $1 \mathrm{ml}$ of HPLC grade methanol.

HPLC analysis was performed using Chen $\mathrm{X}$ et al method with slight modification [22]. SCL - 10A VP HPLC system (Shimadzu, Japan). Reverse phase separation was performed at room temperature $25^{\circ} \mathrm{C}$ using C-18 HYPERSIL column $(250 \times 4.6 \mathrm{~mm})$, particle size $5 \mathrm{~mm}$. The mobile phase consisted of $60 \%$ water i.e. (water containing $0.5 \% \mathrm{H}_{3} \mathrm{PO}_{4}$ and methanol) (solvent $\mathrm{A}$ ) and $40 \%$
Acetonitrile (solvent B). The flow rate was kept at $1 \mathrm{ml} /$ min and the injection volume was $20 \mu \mathrm{l}$. The chromatogram peaks were detected at $254 \mathrm{~nm}$. Detector used was SCL - 10A VP, UV-Visible (Shimadzu, Japan). The compounds were identified by comparing the retention times and peak areas of extracts with that of the reference standard luteolin.

\section{Statistical analysis}

Graphs were prepared in Microsoft office 2010 beta Excel. $\mathrm{IC}_{50}$ value was calculated using the linear regression equation in GraphPad Prism 5.0. Data was represented as mean \pm standard error of mean of three samples. Statistical significance $(p)$ was calculated by one-way ANOVA followed by Tukey's post hoc test of significance where, $p<0.05$ was considered to be significant. Statistical comparison between the mean \% viability of each extract and its negative control was done using one-way ANOVA followed by Dunnett's post hoc test of significance wherein $p<0.05$ and $p<0.01$ were considered to be statistically significant and very statistically significant compared to negative control.

\section{Result}

\section{In vitro MTT assay}

The ethanolic, aqueous and petroleum ether extracts of A.carnosus were evaluated for cytotoxicity against breast adenocarcinoma cell line BT-549 using MTT (3- $(4,5-$ dimethylthiazol-2-yl)-2, 5-diphenyltetrazolium bromide) assay. The cytotoxicity results clearly establish that the petroleum ether and ethanolic extract of A.carnosus exhibits potent cytotoxic effect against BT-549 with an $\mathrm{IC}_{50}$ of $18.35 \mu \mathrm{g} / \mathrm{ml}$ and $58.6 \mu \mathrm{g} / \mathrm{ml}$. Further, both extracts showed dose-dependent inhibition of cell growth. The aqueous extract, conversely showed comparatively less pronounced cytotoxic effect with an $\mathrm{IC}_{50}$ of $238.9 \mu \mathrm{g} / \mathrm{ml}$ (Table 1 and Figure 1). Tukey's post hoc tests indicated comparable cytotoxic activity between petroleum ether extract and paclitaxel as indicated in Table 1. Dunnett's post hoc test displayed significant difference between the mean \% viability of different concentrations of A.carnosus extracts and their corresponding negative control (DMSO).

\section{In vitro SRB assay}

The ethanolic, aqueous and petroleum ether extracts of $A$. carnosus were evaluated for cytotoxicity against breast adenocarcinoma cell line BT-549 using SRB ( Sulforhodamine B) assay (Table 2 and Figure 2). Like MTT assay, results of SRB distinctly prove that petroleum ether extract and ethanolic extract of Anisochilus carnosus showed potent dose- dependent cytotoxic effect against BT-549 with an $\mathrm{IC}_{50}$ of $22.5 \mu \mathrm{g} / \mathrm{ml}$ and $87.24 \mu \mathrm{g} / \mathrm{ml}$ respectively. The aqueous extract, however showed less cytotoxic effect with 
Table 1 Cytotoxicity results of A.carnosus extracts by MTT assay

\begin{tabular}{ccccc}
\hline $\begin{array}{c}\text { Concentration } \\
(\boldsymbol{\mu} \mathbf{g} / \mathbf{m l})\end{array}$ & \multicolumn{3}{c}{ \% Viability } \\
\cline { 2 - 5 } & Aqueous extract & Ethanolic extract & Pet. ether extract & Paclitaxel \\
\hline 0 & $100 \pm 5.875$ & $100 \pm 5.875$ & $100 \pm 5.875$ & $100 \pm 2.09$ \\
6.25 & - & - & - & $80.32 \pm 0.366^{* *}$ \\
12.5 & - & - & - & $42.56 \pm 1.863^{* *}$ \\
25 & $94.04 \pm 1.729$ & $75.26 \pm 2.654^{*}$ & $44.92 \pm 2.631^{* *}$ & $22.83 \pm 1.22^{* *}$ \\
50 & $80.87 \pm 2.462^{*}$ & $54.14 \pm 4.610^{* *}$ & $30.23 \pm 3.662^{* *}$ & $10.66 \pm 0.46^{* *}$ \\
100 & $71.12 \pm 1.950^{* *}$ & $26.66 \pm 2.951^{* *}$ & $12.73 \pm 4.242^{* *}$ & - \\
200 & $58.79 \pm 2.278^{* *}$ & $12.06 \pm 1.104^{* *}$ & $8.16 \pm 1.063^{* *}$ & \\
$I_{50}$ value & 238.91 & $58.64^{\mathrm{a}}$ & $18.35^{\mathrm{a}, \mathrm{b}}$ & \\
\hline
\end{tabular}

Results were expressed as Mean \pm SEM $(n=3)$ and analysed using one-way ANOVA followed by Tukey's post hoc test of significance [where different alphabets denote significant difference $(p<0.05)$ ]. Statistical comparison between the mean $\%$ viability of each extract and its negative control was performed using one-way ANOVA followed by Dunnett's post hoc test of significance wherein ${ }^{*} p<0.05$ and ${ }^{* *} p<0.01$ were considered to be statistically significant and very statistically significant compared to negative control. A.carnosus extracts were tested at concentrations of 200, 100, 50, $25 \mu \mathrm{g} / \mathrm{ml}$ (they were not tested at concentrations of 6.25 and $12.5 \mu \mathrm{g} / \mathrm{ml}$ ). Paclitaxel was tested at concentrations of $6.25,12.5,25$ and $50 \mu \mathrm{g} / \mathrm{ml}$.

an $\mathrm{IC}_{50}$ of $211.26 \mu \mathrm{g} / \mathrm{ml}$. Tukey's post hoc test revealed comparable cytotoxic activity between petroleum ether extract and paclitaxel. Dunnett's post hoc test showed significant difference between the mean \% viability of different concentrations of A.carnosus extracts and their corresponding negative control (DMSO).

Overall, cytotoxicity of A.carnosus extracts against BT549 cell line followed a similar trend by both MTT and SRB assay.

\section{HPLC estimation of Luteolin}

The estimation of luteolin content in various extracts (ethanolic and aqueous) with luteolin as the marker compound was performed using HPLC (High performance Liquid Chromatography). Luteolin eluted at RT 4.542 in both ethanolic and aqueous extract (as can be seen in chromatograms in Figure 3A-C). The results shown in Table 3 and Figure 3(A-C) indicate that the ethanol extract of $A$. carnosus contains the highest concentration of luteolin $(0.372 \% \mathrm{w} / \mathrm{w})$. The aqueous extract contained lower concentration of luteolin $(0.282 \% \mathrm{w} / \mathrm{w})$.

The cytotoxic activity of ethanolic extract is probably due to the presence of luteolin. The presence of luteolin in ethanolic extract is evidently demonstrated through HPLC fingerprinting (Figure 3).

\section{Discussion}

Phytocompounds have been an excellent source of drug leads since several decades. They are unique in that they present an eclectic range of structural diversity and are by nature "biologically friendly" [23]. A recent survey of the European anticancer drug market revealed that of the 155

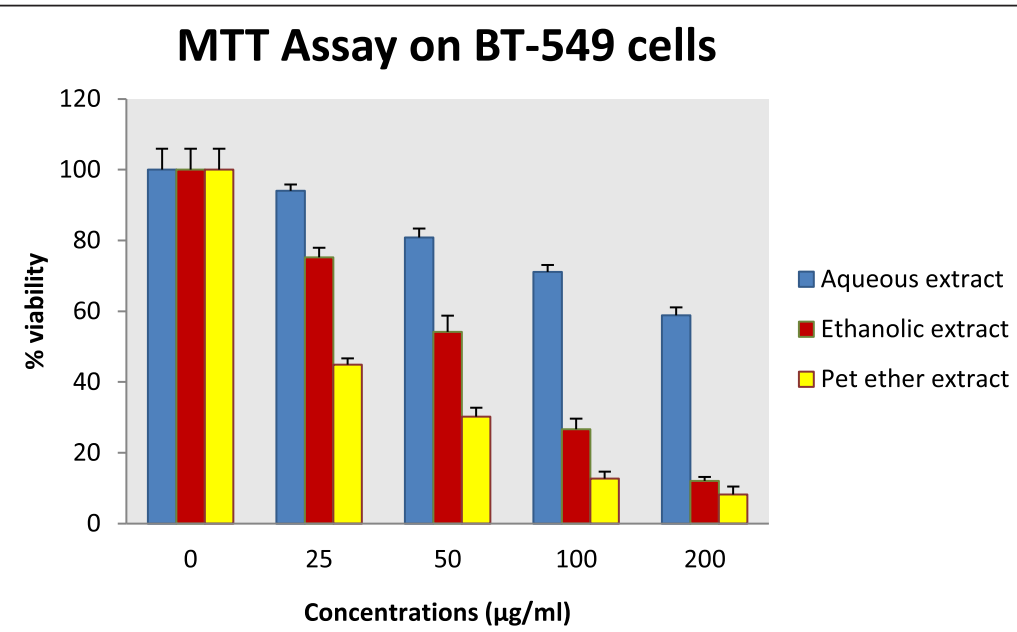

Figure 1 In vitro MTT assay on BT-549 cells. BT-549 cells were incubated with different concentrations (25, 50, 100, 100 mg/ml) of aqueous, ethanolic and petroleum ether extracts of Anisochilus carnosus. Growth inhibition was determined by the MTT assay. The percentage of cell survival was calculated by defining the absorption of cells without Anisochilus carnosus treatment as 100\%. 
Table 2 Cytotoxicity results of A.carnosus extracts by SRB assay

\begin{tabular}{|c|c|c|c|c|}
\hline \multirow{2}{*}{$\begin{array}{l}\text { Concentration } \\
\qquad(\mu \mathrm{g} / \mathrm{ml})\end{array}$} & \multicolumn{4}{|c|}{$\%$ Viability } \\
\hline & Aqueous extract & Ethanolic extract & Pet. ether extract & Paclitaxel \\
\hline 0 & $100 \pm 6.198$ & $100 \pm 6.198$ & $100 \pm 6.198$ & $100 \pm 2.44$ \\
\hline 6.25 & - & - & - & $86.25 \pm 0.441^{* *}$ \\
\hline 12.5 & - & - & - & $45.36 \pm 0.582^{* *}$ \\
\hline 25 & $89.50 \pm 0.883$ & $80.57 \pm 1.972^{*}$ & $46.68 \pm 5.838^{* *}$ & $29.51 \pm 1.54^{* *}$ \\
\hline 50 & $71.01 \pm 2.141^{* *}$ & $59.04 \pm 3.507^{* *}$ & $36.89 \pm 3.525^{* *}$ & $16.46 \pm 2.313^{* *}$ \\
\hline 100 & $61.44 \pm 1.129^{* *}$ & $36.38 \pm 1.396^{* *}$ & $18.73 \pm 2.505^{* *}$ & - \\
\hline 200 & $52.43 \pm 0.745^{* *}$ & $11.85 \pm 2.371^{* *}$ & $10.84 \pm 2.741^{* *}$ & - \\
\hline $\mathrm{IC}_{50}$ value & 211.26 & 87.24 & $22.5^{\mathrm{a}}$ & $13.91^{\mathrm{a}}$ \\
\hline
\end{tabular}

Results were expressed as Mean \pm SEM $(n=3)$ and analysed using one-way ANOVA followed by Tukey's post hoc test of significance [where different alphabets a, b denote significant difference $(p<0.05)$ ]. Statistical comparison between the mean \% viability of each extract and its negative control was performed using oneway ANOVA followed by Dunnett's post hoc test of significance wherein ${ }^{*} p<0.05$ and ${ }^{* *} p<0.01$ were considered to be statistically significant and very statistically significant compared to negative control. A.carnosus extracts were not tested at concentrations of $200,100,50,25 \mu \mathrm{g} / \mathrm{ml}$ (they were not tested at concentrations of 6.25 and $12.5 \mu \mathrm{g} / \mathrm{ml}$ ). Paclitaxel was tested at concentrations of $6.25,12.5,25$ and $50 \mu \mathrm{g} / \mathrm{ml}$.

clinically approved anti-tumor drugs, $47 \%$ were either completely of natural origin or derived therefrom [24].

A.carnosus, a plant that grows commonly in high altitude regions has been attributed with innumerable benefits in folk medicine. Recently, a study has indicated nanoparticles synthesised from A.carnosus extract to show potent antimicrobial activity against microbes such as B. subtilis, K. pneumonia, E.coli and P.aeruginosa [25]. Azmathulla et al. [26] investigated the antiulcer property of A.carnosus and it was found to possess powerful gastric healing properties. Several reports have also shown A.carnosus ethanol extract to be an effective hepatoprotective agent [27,28]. Furthermore, A.carnosus leaves showed good analgesic and antipyretic activity [29]. Such strong pharmacological activity of $A$. carnosus could be credited to the innumerable phytocompounds present in them.

In the present study, we have evaluated the cytotoxic potential of A.carnosus extracts using MTT and SRB assay.
MTT assay establishes the cell viability on the basis of reduction of yellow tetrazolium MTT to purple formazan dye by mitochondrial dehydrogenase enzyme, an enzyme exclusively present in viable cells. As such, the quantity of formazan reveals the number of metabolically active viable cells [30]. The petroleum ether and ethanolic extract of A.carnosus showed potent cytotoxic potential against BT-549 with an $\mathrm{IC}_{50}$ of $18.35 \mu \mathrm{g} / \mathrm{ml}$ and $58.6 \mu \mathrm{g} / \mathrm{ml}$ respectively. Further, both extracts showed dose-dependent inhibition of tumor cell growth. The aqueous extract also displayed dose dependent cytotoxicity against BT-549 cell line with an $\mathrm{IC}_{50}$ of $238.9 \mu \mathrm{g} / \mathrm{ml}$ (Table 1 and Figure 1). According to the United States NCI plant screening program, a plant extract is usually considered to have active cytotoxic effect, if its IC50 value is $30 \mu \mathrm{g} / \mathrm{ml}$ or less [31]. Skehan and his coworkers conceived a novel method called Sulforhodamine B (SRB) assay to determine the cytotoxicity and cell proliferation based on the measurement of cellular protein content [32]. The petroleum ether and ethanolic extract of $A$.

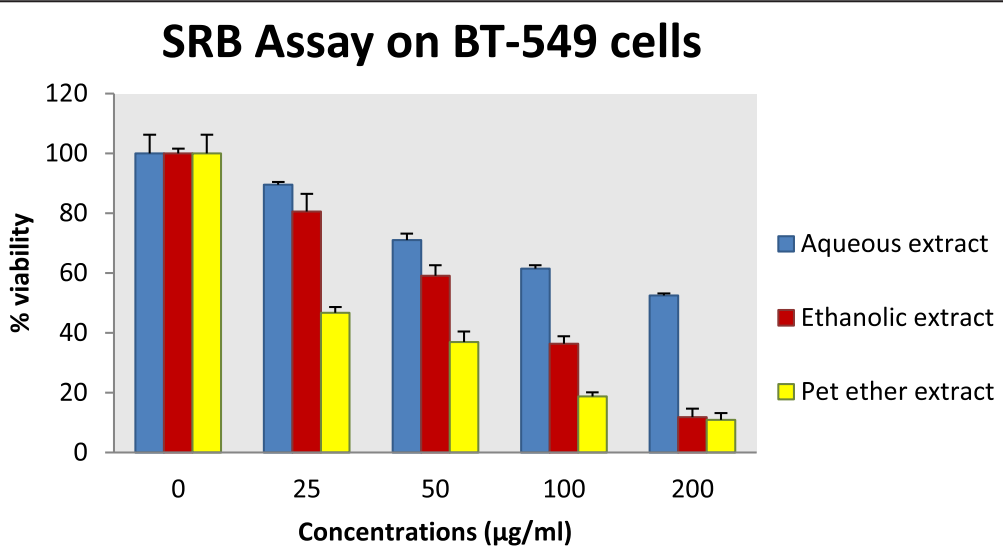

Figure 2 In vitro SRB assay on BT-549 cells. BT-549 cells were incubated with different concentrations (25, 50, 100, 100 $\mu \mathrm{g} / \mathrm{ml})$ of aqueous, ethanolic and petroleum ether extracts of Anisochilus carnosus. Growth inhibition was determined by the SRB assay. The percentage of cell survival was calculated by defining the absorption of cells without Anisochilus carnosus treatment as 100\%. 


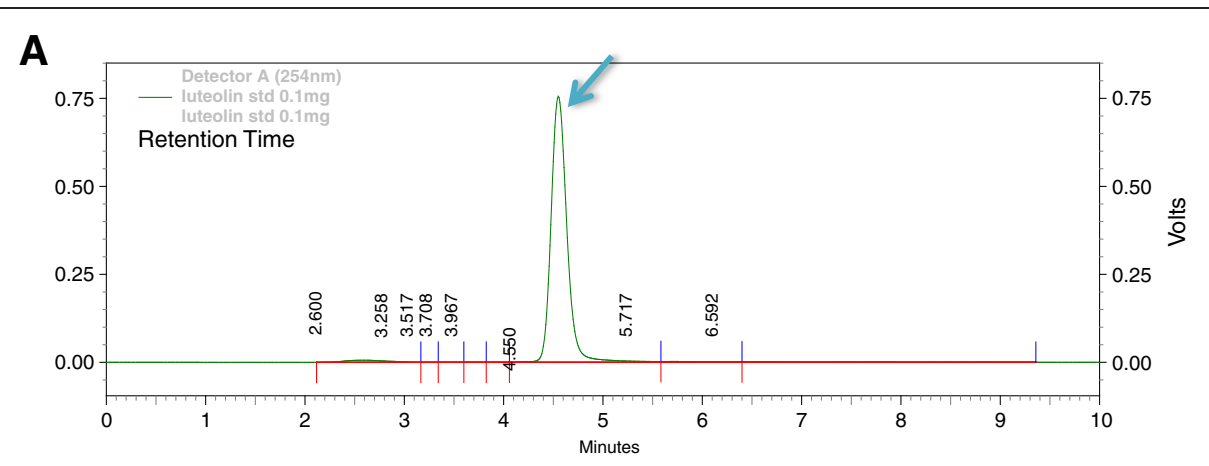

B

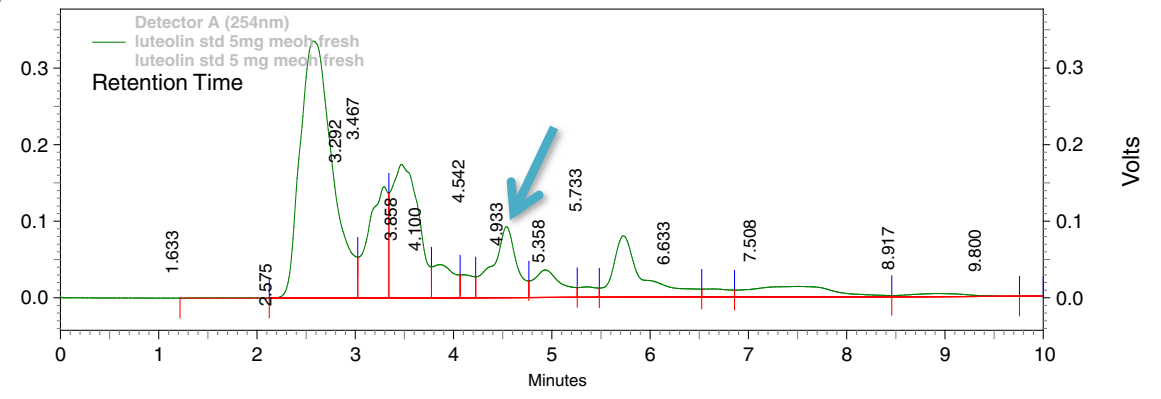

C

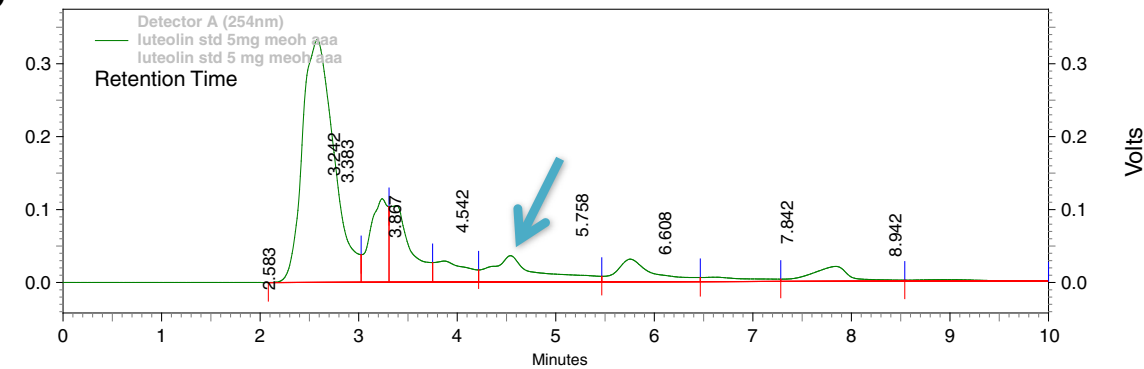

Figure 3 Estimation of Luteolin in A.carnosus extracts. Representative chromatograms illustrate High Performance Liquid Chromatography (HPLC) of luteolin (A), ethanolic extract (B) and aqueous extract (C). Absorbance was measured at $254 \mathrm{~nm}$. Luteolin eluted at RT 4.5. The arrow marks indicate the location of luteolin peak.

carnosus showed high cytotoxicity against BT-549 by SRB assay with an $\mathrm{IC}_{50}$ of $22.5 \mu \mathrm{g} / \mathrm{ml}$ and $87.24 \mu \mathrm{g} / \mathrm{ml}$ respectively. Additionally, both extracts exhibited dose-dependent inhibition of cell growth. The aqueous extract also demonstrated dose dependent cytotoxicity with an $\mathrm{IC}_{50}$ of $211.26 \mu \mathrm{g} / \mathrm{ml}$ (Table 2 and Figure 2). The mean \% viability of all three extracts of A.carnous at concentrations of 50,100 and $200 \mu \mathrm{g} / \mathrm{ml}$ was observed to be

Table 3 Estimation of Luteolin by HPLC

\begin{tabular}{ccccc}
\hline S. no & Sample & Retention time & Peak area & $\begin{array}{c}\text { Concentration } \\
(\% \mathbf{w} / \mathbf{w})\end{array}$ \\
\hline 1 & Luteolin & 4.550 & 8385954 & 100 \\
2 & Ethanolic extract & 4.542 & 1557755 & 0.372 \\
3 & Aqueous extract & 4.542 & 1183180 & 0.282 \\
\hline
\end{tabular}

significantly different from their corresponding negative control (0.01\% DMSO) by both cytotoxicity assays.

It was noted that $\mathrm{IC}_{50}$ values attained through MTT and $\mathrm{SRB}$ assay were highly comparable. A.carnosus aqueous extract gave a slightly higher $\mathrm{IC}_{50}$ value by MTT assay. $\mathrm{IC}_{50}$ values of ethanolic and petroleum ether extracts, on the other hand were found to be comparable though somewhat higher by SRB assay. Overall, there was good correlation between $\mathrm{IC}_{50}$ values obtained by both cytotoxicity assays, thereby confirming that A.carnosus extracts possess potent cytotoxicity.

We observed that aqueous extract of A.carnosus displayed comparatively less cytotoxic activity against BT-549 cell line than petroleum ether and ethanolic extract. Typically, a plant's aqueous extract exerts cytotoxicity at comparatively higher concentration (approximately $250 \mu \mathrm{g} / \mathrm{ml}$ ) than extracts obtained from other solvents 
such as methanol, ethyl acetate, ether etc. [33]. This is probably because water extracts in general, are thought to comprise of highly polar constituents such as carbohydrates, glycosides, proteins and minerals [34]. Moreover, phytochemical screening of A.carnosus successive water extract revealed the presence of constituents such as carbohydrates, glycosides, saponins and tannins in the water extract [18]. Specifically, phytosterols were absent in A.carnosus aqueous extract. As a general rule, phytosterols are insoluble in water, but soluble in nonpolar solvents (like hexane, iso-octane and 2-propanol) [35]. Hence, the possibility of phytosterols being extracted into water is very less. Numerous studies have credited phytosterols with potent cytotoxic activity [36]. We presume the absence of phytosterols and terpenoids in aqueous extract could be a probable reason for low cytotoxic activity of water extract.

Reactive oxygen species (ROS), generated as a result of oxidative stress has been implicated in the development of cancer. ROS are capable of initiating signaltransduction pathways and inducing the transcription of proto-oncogenes such as c-fos, c-jun, c-myc, all of which are involved in accelerating the tumor growth [37]. Antioxidants, well-known for their high ROS scavenging potential are able to protect the cells from ROS attack and may thereby play a crucial role in the prevention of cancer [38]. The ROS scavenging potential of A.carnosus was investigated by Lobo $\mathrm{R}$ et al [39] and it was observed that the methanolic and aqueous extracts of A.carnosus exhibited potent antioxidant activity. We believe the high ROS scavenging potential of $A$. carnosus extracts could be a probable cause for its potent cytotoxic effect.

Several studies have indicated phytosterols to have tremendous antitumor potential. Being the counterparts of cholesterol in plants, they resemble cholesterol structurally, except for the $\mathrm{C}_{24}$ position on the sterol side chain $[36,40]$. The anticancer effects of $\beta$-sitosterol, a dietary phytosterol have been documented in colon [41], breast [42] and prostate cancer [43]. In fact, $16 \mu \mathrm{mol} / \mathrm{L} \beta$ sitosterol was able to induce cell death in MDA-MB-231 breast cancer cell line and LNCaP prostate cancer cell line four to six fold higher than control levels after 3-5 days of treatment [36]. In 1980, Raicht et al. [44] also reported that dietary $\beta$-sitosterol can provide protection from chemically induced colon cancer. They studied the development of methylnitrosourea induced tumor in rats fed with $0.2 \% \beta$-sitosterol in their diet for 28 weeks. A remarkable decline was observed both in the number of rats that developed the tumor and the number of tumors per rat with $\beta$-sitosterol feeding. Besides, dietary supplementation of $\beta$-sitosterol at $60 \mathrm{mg} /$ day for 6 months helped to improve the clinical symptoms of prostatic hyperplasia in humans [45], a disorder characterized by polyuria due to the enlargement of the prostate gland. For the same reason, epidemiologic studies propose a link between lower levels of prostatic cancer in Asians and vegetarians with diets rich in phytosterols compared with the Western diet [46]. Phytochemical screening of A.carnosus indicated the presence of phytosterols in the petroleum ether successive extract [18]. Consequently, the high cytotoxic activity of the petroleum ether extract reported in this study could be credited to the phytosterols present in A.carnosus petroleum ether extract.

Flavonoids are another group of nutritional phytochemical that has been widely acknowledged for its remarkable cancer-protective effects. Luteolin, a naturally occurring flavonoid exhibits powerful antitumor potential. Samy et al. [47] evaluated the anti-tumour potential of luteolin and cyclophosphamide combination against DMBA induced mammary carcinogenesis in Wistar rats and it was observed that the combination treatment reduced the incidence of tumour and decreased the tumour volume. Also, in a DMH induced colon cancer model, luteolin administration decreased the occurrence of colon cancer, total number and mass of tumors per rat by almost $90 \%$ in a dose-dependent manner both in initiation and post-initiation stages of colon carcinogenesis [48]. Luteolin isolated from Terminalia arjuna was found to inhibit proliferation of MCF-7breast cancer and HepG2 liver cancer cells in a dose dependent manner [49]. Luteolin also stalled proliferation of various tumour cell lines in vitro such as epidermoid, pancreatic, hepatoma, esophageal and lung cancer cell lines [50]. Hence, the potent cytotoxic activity of ethanolic extract of A.carnosus reported in this study can be attributed to its luteolin content. This is the first report on cytotoxicity of different extracts of A.carnosus against BT-549 breast adenocarcinoma cell line.

\section{Conclusion}

The petroleum ether and ethanolic extracts showed remarkable cytotoxic activity against BT-549, an estrogen independent breast carcinoma cell line. It can thus be concluded that these extracts have the potential to be developed as a chemopreventive option for cancer. However, it is very difficult to conclude the possible mechanism for their cytotoxic activity at this stage. Hence, further research in this direction can be attempted to elucidate the molecular mechanism. Besides, they can be screened against other cancer cell lines for cytotoxic activity.

\section{Abbreviations}

A.carnosus: Anisochilus carnosus; HPLC: High performance liquid chromatography; MTT: (3-(4, 5-dimethylthiazol-2-yl)-2, 5-diphenyltetrazolium bromide); SRB: Sulforhodamine B; MEM: Minimum essential medium.

\section{Competing interest}

The authors declare that they have no competing interest. 


\section{Authors' contributions}

$J K B, N K$ and AP have carried out the communicated work. RL has supervised and guided the above research work. JEW has supervised and co-guided the above work. All authors have read and approved the final manuscript.

\section{Acknowledgement}

The authors thank Manipal University, Manipal College of Pharmaceutical Sciences, Manipal, India for providing the facilities to carry out this study.

\section{Author details}

${ }^{1}$ Department of Pharmacognosy, Manipal College of Pharmaceutical Sciences, Manipal University, Manipal, Karnataka 576 104, India. ${ }^{2}$ Department of Pharmaceutical Chemistry, Manipal College of Pharmaceutical Sciences, Manipal University, Manipal, Karnataka 576 104, India.

Received: 16 August 2014 Accepted: 17 October 2014 Published: 28 October 2014

\section{References}

1. Buchholz TA: Radiation therapy for early-stage breast cancer after breastconserving surgery. N Engl J Med 2009, 360:63-70

2. Holmes CD, Silverman P: Breast cancer: overview \& updates. Nurse Pract 2011, 36:20-27.

3. Surveillance, Epidemiology and End Results (SEER) program [Internet] [Accessed 2014 Februaury 24] [http://seer.cancer.gov/statfacts/html/breast. $\mathrm{html}]$

4. Zienolddiny S, Haugen A, Lie JAS, Kjuus H, Anmarkrud KH, Kjærheim K: Analysis of polymorphisms in the circadian related genes and breast cancer breast cancer risk in Norwegian nurses working night shifts. Breast Cancer Res 2013, 15:R53.

5. Boer-Dennert M, Wit' R, Schmitz P, Djontono J, Beurden' V, Stoterl G, Verweij $\mathrm{J}$ : Patient perceptions of the side-effects of chemotherapy: the influence of 5HT3 antagonists. Br J Cancer 1997, 76:1055-1061.

6. Curt GA, Breitbart W, Cella D, Groopman JE, Horning SJ, Itri LM, Johnson DH Miaskowski C, Scherr SL, Portenoy RK, Vogelzang NJ: Impact of cancerrelated fatigue on the lives of patients: new findings from the fatigue coalition. Oncologist 2000, 5:353-360.

7. Surh YJ: Cancer chemoprevention with dietary phytochemicals. Nat Rev 2009, 3:768-779.

8. Al-Daghri NM, Alokail MS, Alkharfy KM, Mohammed AK, Abd-Alrahman SH, Yakout SM, Amer OE, Krishnaswamy S: Fenugreek extract as an inducer of cellular death via autophagy in human T lymphoma Jurkat cells. BMC Complement Altern Med 2012, 12:202-210.

9. Sasaki N, Toda T, Kaneko T, Baba M, Matsuo M: Protective effects of flavonoids on the cytotoxicity of linoleic acid hydroperoxide toward rat pheochromocytoma PC12 cells. Chem Biol Interact 2003, 145:101-116.

10. Ayyanar M, Sankarasivaraman K, Ignacimuthu S: Ethnobotanical investigations among tribes in Madurai District of Tamil Nadu (India). J Ethnobiol 2006, 2:25.

11. Indian Biodiversity Portal [Internet]. [Accessed 2014 January 9] [http:// indiabiodiversity.org/species/show/228744]

12. Kamble SY, Patil SR, Sawant PS, Sawant S, Pawar SG, Singh EA: Studies on plants used in traditional medicine by bhilla tribes in Maharastra. Indian J Traditional Knowledge 2010, 9:591-598.

13. Mohammed A, Kumar RJ, Santosh HY, Nagashruthi MH: Antiulcer activity of Anisochilus carnosus leaf extracts in pylorus ligation rats. Indian Drugs 2008, 45:979.

14. Ignacimuthu S, Ayyanar M, Sankara SK: Ethnobotanical investigations among tribes in Madurai District of Tamil Nadu (India). J Ethnobiol Ethnomed 2006, 2:25.

15. Ganesan S, Suresh N, Kesaven L: Ethnomedicinal survey of lower Palni hills of Tamil Nadu. Indian J Traditional Knowledge 2004, 3:299-304.

16. Usha D, Goyal VC: Traditional Knowledge Systems for Healthcare and Wellness of Elderly People; International Conference on Newer Developments in Drug Discovery from Natural Products and Traditional Medicines. 2008.

17. Khare CP: Indian Medicinal Plants: An Illustrated Dictionary. 1st edition. Springer Reference; 2007:52-53.

18. Lobo R, Bhagat J, Ballal M, Gupta N: Histo-anatomical Study of Anisochilus carnosus (L.f.) Wall: An Indian Habitant. Res J Med Plant 2012, 6:456-460.

19. Felice S, Francesca L, Francesca V, Maurizio B, Francesco N: Composition and Antibacterial activity of the essential oil of Anisochilus carnosus
(Linn. fil.) Benth., a Tamil plant acclimatized in Sicily. Flavour Frag J 2003, 18:202-204

20. Mossman T: Rapid colorimetric assay for cellular growth and survival: application to proliferation and cytotoxicity assays. J Immunol Method 1983, 65:55-63.

21. Houghton P, Fang R, Techatanawat I, Steventon G, Hylands PJ, Lee CC: The sulphorhodamine (SRB) assay and other approaches to testing plant extracts and derived compounds for activities related to reputed anticancer activity. Methods 2007, 42:377-387.

22. Chen X, Liu L, Sun Z, Liu Y, Xu J, Liu S, Huang B, Ma L, Yu Z, Bi K Pharmacokinetics of luteolin and tetra-acetyl-luteolin assayed by HPLC in rats after oral administration. Biomed Chromatogr 2010, 24:826-832.

23. Pan $L$, Kinghorn D: Discovery of new anticancer agents from higher plants. Front Biosci 2013, 4:142-156.

24. Pan $L$, Chai $H$, Kinghorn D: The continuing search for antitumor agents from higher plants. Phytochemistry Letters 2010, 3:1-8.

25. Syed A, Vijaya PP, Saranya RS, Yogananth N, Anurath A, Parveen PK: Antimicrobial activity and characterization of biosynthesized silver nanoparticles from Anisochilus carnosus. Int J Nano Dimens 2013, 4:255-262.

26. Azmathulla M, Ha R, Koshy RK, Mohan M: Effect of methanolic extracts of leaves Anisochilus carnosus on gastric and duodenal ulcers in rats. Int J Res Pharm Biomed Sci 2011, 2:1643-1650.

27. Venkatesh P, Dinakar A, Kumar S: Hepatoprotective activity of an ethanolic extract of stems of Anisochilus carnosus against carbon tetrachloride induced hepatotoxicity in rats. Int J Pharm Pharm Sci 2011, 3:243-245.

28. Verma P, Samanta KC, Sharma V: Hepatoprotective activity of alcoholic and aqueous extracts of leaves of Anisochilus carnosus (L) Wall. Int J Pharma Res Dev 2010, 2:106-109.

29. Venkatesh P, Dinakar A, Kumar S: Evaluation of analgesic and antipyretic activity of alcoholic extracts of Boerhaavia Diffusa and Anisochilus Carnosus. J Curr Pharm Res 2012, 10:15-19.

30. Loosdrecht V, Beelan RHJ, Ossenkoppele GJ, Broekhoven MG, Langenhuijsen MMAC: A tetrazolium-based colorimetric MTT assay to quantitate human monocyte mediated cytotoxicity against leukemic cells from cell lines and patients with acute myeloid leukemia. J Immunol Methods 1994, 174:311-320.

31. Lee CC, Houghton P: Cytotoxicity of plants from Malaysia and Thailand used traditionally to treat cancer. J Ethnopharmacol 2005, 100:237-243.

32. Voiqt W: Sulforhodamine B assay and chemosensitivity. Methods Mol Med 2005, 110:39-48

33. Mothana RA, Lindequist $U$, Gruenert R, Bednarski PJ: Studies of the in vitro anticancer, antimicrobial and antioxidant potentials of selected Yemeni medicinal plants from the island Soqotra. BMC CAM 2009, 9:7-18.

34. Radovanovic AM, Cupara SM, Popovic SL, Tomovic MT, Violeta N, Slavkovska VN, Jankovic SM: Cytotoxic effect of Potentilla reptans I. Rhizome and aerial part extracts. Acta Poloniae Pharmaceutica - Drug Research 2013, 70:851-854

35. Cantrill R: Phytosterols, Phytostanols and their esters (Chemical and Technical Assessment). In PhD Thesis, JECFA Meeting. ; 2008:1-13.

36. Awad AB, Fink CS: Phytosterols as anticancer dietary components: evidence and mechanism of action. J Nutr 2000, 130:2127-2130.

37. Widowati W, Wijaya L, Wargasetia TL, Bachtiar I, Yellianty Y, Lakshmitawati DR: Antioxidant, anticancer, and apoptosis-inducing effects of Piper extracts in HeLa cells. J Exp Integr Med 2013, 3:225-230.

38. Waris $\mathrm{G}$, Ahsan $\mathrm{H}$ : Reactive oxygen species: role in the development of cancer and various chronic conditions. Journal of Carcinogenesis 2006, 5:14-22.

39. Bhagat J, Lobo R, Parmar V, Ballal M: In vitro free radical scavenging potential of Indian habitant Anisochilus carnosus(L.F.) Wall. Chin J Nat Med 2011, 9:456-460

40. Ju YH, Clausen LM, Allred KF, Almada AL, Helferich WG: $\beta$-Sitosterol, $\beta$-Sitosterol glucoside, and a mixture of $\beta$-Sitosterol and $\beta$-Sitosterol glucoside modulate the growth of estrogen responsive breast cancer cells in vitro and in ovariectomized athymic mice. J Nutr 2004 134:1145-1167.

41. Awad AB, Chen YC, Fink CS, Hennessey T: $\beta$-Sitosterol inhibits HT-29 human colon cancer cell growth and alters membrane lipids. Anticancer Res 1996, 16:2797-2804.

42. Downie A, Fink CS, Awad AB: Effect of phytosterols on MDA-MB-231 human breast cancer cell growth. FASEB J 1999, 13:A333 (abs.) 
43. Von Holtz RL, Fink CS, Awad AB: $\beta$-Sitosterol activates the sphingomyelin cycle and induces apoptosis in LNCaP human prostate cancer cells. Nutr Cancer 1998, 32:8-12.

44. Raicht RF, Cohen LI, Fazzini EP, Sarwal AN, Takahashi M: Protective effect of plant sterols against chemically induced colon tumors in rats. Cancer Res 1980, 40:403-405.

45. Berges RR, Windeler J, Trampisch JH, Senge T: Randomized, placebocontrolled, double-blind clinical trial of b-sitosterol in patients with benign prostatic hyperplasia. Lancet 1995, 345:1529-1532.

46. Mettlin C: Clinical oncology update: prostate cancer. Recent developments in the epidemiology of prostate cancer. Eur J Cancer 1997, 33:340-347.

47. Samy RP, Gopalakrishnakone P, Ignacimuthu S: Anti-tumour promoting potential of Luteolin against 7, 12-dimethylbenz(a)anthracene-induced mammary tumors in rats. Chem Biol Interact 2006, 164:1-14.

48. Vaiyapura $\mathrm{M}$, Namasivayam $\mathrm{N}$ : Chemopreventive potential of Luteolin during colon carcinogenesis induced by 1,2-dimethylhydrazine. Ital J Biochem 2005, 54:268-275.

49. Pettit GR, Hoard MS, Doubek DL, Schmidt JM, Pettit RK, Tackett LP: The cancer cell growth inhibitory constituents of Terminalia arjuna (Combretaceae). J Ethnopharmacol 1996, 53:57-63.

50. Wang $\Pi$, Wang SK, Huang GL, Sun GJ: Luteolin induced-growth inhibition and apoptosis on human esophageal SCC line Eca109 cells in vitro. Asian Pac J Cancer Prev 2012, 13:5455-5460.

doi:10.1186/1472-6882-14-421

Cite this article as: Bhagat et al:: Cytotoxic potential of Anisochilus carnosus (L.f.) wall and estimation of luteolin content by HPLC. BMC Complementary and Alternative Medicine 2014 14:421.

\section{Submit your next manuscript to BioMed Central and take full advantage of:}

- Convenient online submission

- Thorough peer review

- No space constraints or color figure charges

- Immediate publication on acceptance

- Inclusion in PubMed, CAS, Scopus and Google Scholar

- Research which is freely available for redistribution

Submit your manuscript at www.biomedcentral.com/submit
() Biomed Central 